\title{
EMPLOYEES PARTICIPATION RIGHTS - THE TRANSPOSITION OF THE ARTICLE 16 OF DIRECTIVE 2005/56/CE ON CROSS-BORDER MERGER IN THE MEMBER STATES
}

\author{
F. Bejan
}

\section{PhD Felicia Bejan}

Faculty of Political Sciences

University of Bucharest, Bucharest, Romania

*Correspondence: Felicia Bejan, Faculty of Political Sciences, 59 Calea Plevnei, Bucharest, Romania

E-mail: felicia.bejan@fspub.unibuc.ro

\begin{abstract}
The participation right of employees to the administration and supervision of companies is an aspect that may have a significant influence on the profile of a cross-border merger. In European Law, this right is protected through article no. 16 of the Directive 2005/56/EC on cross-border mergers, completed with Regulation(EC) 2157/2001 in the Statute for a European company and with Directive 2001/86/EC supplementing the Statute for a European company with regard to the involvement of employee. The current study aims to offer an analysis of the transposition of the Article 16 of Directive 2005/56/CE on crossborder merger in the national laws of some Member States and to underline the differences between the legal regimes in these legal systems. The research is of interest in the domain, whereas the level of employee participation in different states and a comparative perspective are criteria taken into consideration in the make-decision process regarding the country where the resulting company from a cross-border merger shall set up its headquarter.
\end{abstract}

KEYWORDS: employee participation rights, cross-border merger, special negotiating body, management and supervision bodies, agreements on employees involvement, employee influence.

\section{INTRODUCTION.}

Company reorganization through cross-border merger has legal effects on the employee rights. The most well-known rights are those regarding the safeguarding of the employee rights established in their individual and collective labor contracts, which benefit of a special legal protection through the Directive 2001/23/EC, transposed into national legal system by the Member States ${ }^{1}$.

Other rights that may be affected by such reorganization are less addressed in our juridical literature ${ }^{2}$ and refers to the employee participation rights in the administration and

\footnotetext{
${ }^{1}$ Regarding the employee protection in the case of company transfer through merger, see I.T. Stefanescu, Theoretical and practical treaty, Bucharest, Universul Juridic Publishing House, 2012, p 466-474; O. Tinca, Critical observation to Law 67/2006 regarding the employees' rights protection in the event of transfer of undertakings, businesses, or part of undertakings or businesses, Law Review, no 2/2007, pp 62-73, A.Uluitu, The employee rights in case of transfers of undertakings, businesses or parts of undertakings, Romanian Journal for Labor Law number 1/2006, pp 28-35 F. Bejan Mergers' implication for employees under Romanian law , AGORA International Journal of Juridical Sciences, no. 3/2013, p.6-13.F.Bejan, Legal aspects of the transposition of the Directive 2001/23/EC regarding the safeguarding of employees rights in the event of transfer in the Romanian Law, Lex Scientia Lesij, Number XX, volume 1/2013, pp 16-23.

2 Regarding the employee participation rights, see B. Keller, The European Company statute-employee involvement-and beyond, "Industrial Relations Journal", Vol. 33, pp. 424-445; F.Bejan, European Union Rules on employee participation right within the framework of cross-bordee merger, Advances in fiscal, poiitical and
} 
supervision of companies. This one does not have a special European legal framework, separated from those stipulated in the general regulation provided by the Directive 2005/56/EC on cross-border merger, under the article 16, entitled "Employee participation". 3 In the absence of a special and detailed regulation in this respect, there are Member States that consider the participation right a very important one and Member States that did not allow the employees to take part to the companies' make-decision process. The present legal framework generates at the same time diversity and differences, advantages and disadvantages for subjects to law involved in a cross-border merger, employers and employees. The study of various regimes concerning the participation rights in the Member States is a compulsory step that can contribute to the adoption of the best possible decision regarding the Member State where the resulting company from the cross-border merger will be established.

\section{EMPLOYEES PARTICIPATION RIGHTS IN THE MEMBER STATES}

\section{Germany.}

Employee participation right is considered as being a very important one in German juridical system.

The employee representatives in companies established in Germany, parties of cross border mergers, exercise their participation rights at the supervisory board level, in which they are assigned in regard to their total number of employees. If in those companies having more than 500 employees, their representatives take up a third of the supervisory board's seats, than in a company with over 2000 employees, their representatives' number equals the number of shareholder representatives.

Given the fact that employee representatives are provided full rights in the supervisory board, including the right to vote, their influence in the adoption of decision in the company resulting from the merger is considerable. The decision-making power of the employee representatives is, to some extent, counterbalanced by the rule of the supervisory council president's casting vote, which is appointed by the shareholders' representatives.

The legal rules stipulated under Article 16 of the cross-border merger Directive 2005/56/EC have been implemented into the German legislation through Employee Participation Act, entered into force on December $29^{\text {th }}, 2006 .{ }^{4}$

In accordance with the Article 4 of the Act, the employee participation in companies resulting from a cross-border merger shall be governed by the law of the member state in which

the resulting company establishes its social headquarters. As a consequence, all resulting companies with headquarters in Germany are bound to apply the German participation system.

The only exceptions are those stipulated under the Article 16(2) of the cross-border merger Directive. Regarding these situations, the dispositions of art 5 of Employee Participation Act provides that it is compulsory to constitute a special body representing the employees having the role of negotiating the legal term of the co-determination regime with the employers' representative.

\footnotetext{
law sciences, Proceedings of the 2nd International Conference on Economics, Political and Law Science (EPLS '13), pp 43-49.

${ }^{3}$ Published in the OJ L 310/1 of November 25, 2005.

${ }^{4}$ Legea Gesetz zur Umsetzung der Regelungen über die Mitbestimmung der Arbeitnehmer bei einer Verschmelzung von Kapitalgesellschaften aus verschiedenen Mitgliedstaaten, din 21. decembrie 2006, publicată în "Bundesgesetzblatt Jahrgang 2006 Teil I" , Bonn , nr. 65, 28. december 2006, p. 332. The Act is available online at: http://www.bmas.de.
} 


\section{Felicia Bejan}

Appointment of German members of the negotiation body is done by an election committee, consisting of at most 40 people that are members of work councils of the participating companies.

Regarding the designation of such employee representatives within German companies with partake in the SNB, in accordance with Article 8 from The Law of Employee Participation in Cross-Border Mergers, the election committee must respect the following requirements:

- election committee members are directly chosen by an employee meeting, in case in which there are no work councils;

- male and female German members of the special negotiation body, are appointed proportionally to the number of male and female employees;

-members of the special negotiation body may be employees of German companies which take part in the merger and syndicate members;

-in case in which the social negotiation body contains at least two German members which are employees, each third member must be a representative of the syndicate;

-in case in which the social negotiation body contains more than six German members which are employees, each seventh member must be a senior executive.

Both the social negotiation body members and employee representatives within the supervisory board are under equal protection. The benefit of this right implies that, in particular, protection against dismissal, protection during meetings within the special negotiation body or the supervisory board, including protection regarding preserving wage employee rights while those in question are exercising their duties, according to Article 32 from The Law of Employee Participation in Cross-Border Mergers.

The German participation model is considered the most complete and powerful within the European Union. Direct participation of employee representatives in administration of the employer's activity and the proportion of their vote in the decision-making process give the participation right consistency. Strict regulation of German SNB members' election and the content of the concession rights ensure the preservation of German employee influence of which employers are engaged in a cross-border merger process within the new legal body.

\section{Austria.}

In contrast to the German legislator, which encourages a large participation of the employees in the employer's mechanisms of decision, the Austrian lawmaker has a reserved approach concerning the employees' oportunities to influence the organisation and the activity of the companies resulting from an operation of cross-border merger.

The dispositions of the cross-border merger Directive concerning the employee participation has been transposed in Austria by Section 258 and the next ones of the Labour Constitutional Law which enterd into force on 15th of December 2007.

According to the Austrian law, the right of participation is granted by letting the employees designate one third of the members of the supervisory board.

Within the special negotiation body there are elected work council members or those of the corresponding sindicates in accordance with the procedure established through the provisions stipulated in the Labour Constitutional Law, sections 217 and 218.

The special negotating body can decide to negotiatiate and conclude a written agreement concerning the participation of the employees or it may choose not to start the negotation or cancel the negotation which has already been started. In the latter, it the Austrian legislation on the employees participation will be applied. More specifically, the employees will designate one third of the members of the supervisory board. 
If the parties do not get to an accord within six months or one year or if the competent bodies of the participating companies decide to not initiate negotations, the standard rules of participation shall be applied. ${ }^{5}$

According to these rules, the number of members of the supervisory board nominated by the employees is based on the highest level of participation in the involved companies and the election of the Austrian members and the allocation of the places in the council is made by the decision of the special negotiating body.

In case in which the management decides not to start negotations regarding the employee participation rights, the law establishes the obligation of notifing the employee representatives regarding this decision. A special nominated group consisting of employees, whose competences are equal to the special negotiating body in similar situations.

Whatever the structure in which they carry out their activities, the employee representatives enjoy the right of being protected, especially against dismissal and discrimination.

As a general feature, the Austrian model of employee participation preserves the permissive nature of the directive. However, unlike the directive which establishes the obligation of protecting the employees for a period of three years after the date of entry into force of cross-border merger, the transposal legislation extends the period of protection from three to five years. It is the only Austrian national disposition more restrictive than the directive concerning the protection of participation rights.

\section{The Netherlands.}

In the Netherlands' law system, the provisions of the Article 16(1) of the Directive 2005/56/CE have not been transposed.

The legislator considered such an approach unnecessary, because it is obvious that the Dutch law as a social headquarters law is applicable in case that the company resulting from the cross-border merger establishes in The Netherlands and has limited itself to introducing within its national law provisions regarding the exception stipulated by Article 16(2) of the Directive.

On the other hand, it is important mention that the community rules regarding the participation laid down by the Regulation SE and the Directive 2011/86/CE have been transposed through special provisions included in the Dutch Civil Code. ${ }^{6}$

The employee participation system in the Dutch law is known as "the regime of structure" and it is regulated by the Article 2:152 and Article 2:262 of the Civil Code.

In essence, what characterizes the regime of structure is the fact that the participation rights' influence is exercised through a work council formed by the employee representatives.

The work council, toghether with the general meeting, has the right to nominate the candidates for a place in the supervisory board of the company and, independently, to make recommendations concerning one third of the members.

The Dutch law regulates the types of the companies and the conditions under which the applicability of the regime of structure by these entities is imperative.

\footnotetext{
${ }^{5}$ The standard rules and the legal rules regarding the employees' rights are only applied in the two hypothesis regulated by the Article 16(3) of the Directive 2005/56/EC regarding cross-border merger, corroborated with the Article 7 (2) (b) din Directive 2001/86/EC supplementing the Statute for a European company with regard to the involvement of employees, and transposed in Austria through the Labour Constitutional Act.

${ }^{6}$ Dutch Civil Code, act available online at: www.dutchcivillaw.com. In Dutcth Law, the Directive on crossborder merger has been transposed in Dutch Cicil Code in 2008 through a normative act, named, Wet van 27 iuni 2008 tot wijziging von boek 2 van het Burgerlijk Wetboek in verband met de implementatie van richtlijn $n r$. 2006/56/EG van het Europese Parlement en de Raad van de Europese Unie betreffende grensoverschrijdende fusies van kapitaalvennootschappen (PbEU L 310), publicat în "Staatsblad".
} 


\section{Felicia Bejan}

So, besides the exceptions provided for by law, the joint stock companies and the limited liability companies have the obligation to apply the regime of structure if in the last three years before the merger the following conditions are cumulatively met:

-the value of the capital and company's reserves is minimum 16 million euros;

-the company or an entity depending on it have in their internal structure, according to the statutory provisions, a work council and

-the company, including the entity that depends on it, as the case may be, has minimum 100 employees in Holland

Nothing stops the companies that do not meet the provisions of the Dutch Civil Code regarding the participation to agree upon creating a work council and adopt the regime of structure.

According to Article 2:333k(2) from the Dutch Civil Code, the applicability rule of the social headquarters law is unnecessary and negotiations have to be initiated in order to establish an employee participation system in one of the following situations :

- any of the merging companies has a number of over 500 employees and applies an employee participation system;

- any of the merging companies applies an employee participation system and the company resulted from the cross-border merger which establishes in Holland does not fulfil the conditions in order to become subject of the regime of structure.

From the interpretation of the cited provisions regarding the negotiation's mandatory nature are emerging some interesting conclusions.

First of all, what is important to underline is that in the Dutch law system, the negotiation of the participation rights is compulsory including the case in which at the merge is participating a dutch company that applies the structure regime. In other words, the negotiation can be mandatory even for dutch participant companies that have minimum 500 employees and apply the regime of structure.

Second of all, the same obligation of negotiation it is necessary in cases in which the Dutch company resulted from the merge does not fulfill the conditions provided by the Civil Code regarding the applicability of the structure regime, but another participant company has known a system of participation.

If we take into consideration that negotiations are delaying the merger procedure and they are consuming resources, and at the end of the negotiation there is the chance that the regime of participation is other than the one of structure, the question that arises is what determined the transposal in such a manner of art. 16(2) of the Directive 2005/56/CE.

In our opinion, the Dutch legislator has opted for this legal solution to respect the spirit of the communitary law and not only its letter. It is the only reason for which the principle of mentaining the employee participation rights has been applied, as an alternative to the legislation which favoured the Dutch companies participanting at the merger operation .

We believe that the absence of the transposal of art 16 (2)(b) of Directive 2005/56/CE, which would have been senseless, given that the regime of structure applied to the company resulting from the cross-border merger assures a participation of the employees at the highest level, has to be interpreted in the same way.

Regarding the establishment and the atributions of the special negotiations body, the negotiation of the participation means, the conditions of the reference provisions applicability and their content, the national Dutch provisions create a balance between the community legislation and the specificities of the national rules from this area.

The employee protection system is shielded for a period of three years after the entry into force of the cross-border merger.

\section{France.}

The transposal of the Directive 2005/56/Ec in the French law has been made through the Law nr 2008-649 from the 3rd of July 2008 and through the Decrees 2008-1116 and 2008- 
1117 from the 3rd of October 2008 which have modified the new French labour code by art. L 2371-1 and the foll. , D 2371-1 and the foll. And R 2371-5 and the foll.

The new Labour Code ${ }^{7}$ establishes the legal framework regarding the creation and functioning of the special negotiating body and the content of the participation agreement.

In the absence of an agreement, the same legislative act provides the creation of a committee of the company resulting from the cross-border merger. ${ }^{8}$

The dispositions of the Labour Code that transpose the directive apply to :

- the absorbing companies or the ones created by the cross-border merger and which establish their social headquarters in France;

- the companies participating in the cross-border merger, having their social headquarters established in France,

- the subsidiaries and branches established in France of a company resulting from the cross-border merger, the social headquarters' center being situated in another member state.

Additional to the regulation in the field of applicability, art. L 2371-2 from the new Labour Code stipulates that "the company resulted from a cross-border merger is not obligated to create rules concerning the participation of the employees if, at the date of the registration, none of the participating companies at the merger wasn't managed according to these rules".

Such a provision only summarises the dispositions of the art 16(1) from the Directive 2005/56/CE in a clearer manner.

Although its introduction in the Labour Code may be considerated superfluous, we believe that the judgement of the French legislator was to remove the possibility of any extensive interpretation concerning the area of participation of the community rule.

In France, a participation system is applicable in the public limited companies where the state is the majority shareholder. These companies' employees have the right to request one third of the places from the council of administration or the council of supervision.

There are also legal cases of participation in the companies of which securities are admited to transactions on a regulated market and whose employees owe more than $3 \%$ from the capital.

Regarding the other companies from the private sector there are no dispositions that can regulate the requierement of the comenegement regime.

Instead, according to the art. L 2252-7 from the French Commercial Code, shareholders may add to their status an employee system of participation.

The particularity of the French law system consist of the fact that the majority of the potential participants at a cross-border merger can apply only one conventional employee participation system. As a consequence, the companies with wholy shareholding or a private majority from France may be administrated with the participation of the employees, only if the owners agree this way.

From our point of view, the regulation of the participation rights in the French law represents the expresion of the reserve that France has shown since the negotations that preceded the adoption of the Regulation SE and the Directive 2001/86/CE. The French legislator gives the investors the freedom of deciding with regard to the way they organize themselves so that the decision-making process is proportionate to their personal needs and interests.

\footnotetext{
${ }^{7}$ The New French Labour Code enter into force at 1st of May 2008;

8 The competences, formation and functioning of the committee, are governed by the Articles. L.2353-3 L.2353-27 of Labor Code. In French juridical literature, the requirement to create a committee is contested. This mechanism is considered inefficient, because , in practice, does not allow the employee participation;
} 


\section{Felicia Bejan}

\section{EMPLOYEES PARTICIPATION RIGHTS IN ROMANIA.}

Romania is one of the Member States that does not have a employee participation system regarding the companies' management bodies.

According to Romanian law, the establishment of employee participation modalities is not compulsory every time the company resulting from the cross-border merger is a Romanian legal person.

Law no 31/1990, under Article $251^{10}$ has introduced into national legal system provisions safeguarding the "before-after" principle.

The project of cross-border merger shall include "where applicable, informations concerning the mechanisms of involvement of the employees in defining their rights of participation at the activity sustained by the absorbing or newly created company", as it's stipulated under the Article $251^{13}$ (4) of Law no. 31/1990 regarding trade companies.

The acting judge has the competence to verify, if necessary, "the characteristics of the employees involvement mechanisms in the activity of the absorbing or newly created company", as Article $251^{13}$ (4) of Law no. 31/1990 stipulates.

From the interpretation of the paragraph (1) and (2) of art. 251 of Law nr. 31/1990 it results that the absence of a participation regulation leads to the following consequences regarding the area of applicability of the "before-after" principle :

-the absorbing or newly created company with the statutory headquarters in Romania resulting from the cross-border merger does not have the obligation to establish a mechanism of participation if the employees did not previously benefit of the right of participation in none of the participating companies;

-the absorbing or newly created company with the statutory headquarters in Romania resulting from the cross-border merger has the obligation to create a participation system in case if at least one of the participating companies have applied such a regime before the merge.

In conclusion, if the absorbing or newly created company with the statutory headquarters in Romania resulting from the cross-border merger or at least one of the companies that merge has a mechanism of employee involvement in the activity of the company, the participating companies' managers have the imperative obligation to introduce employee participation mechanisms.

The establishment of the employee participation rights is achieved according to the dispositions of Article 251 of the Law 31/1990 corroborated with the ones belonging to the Government Decision no $187 / 2007$ concerning the procedures of information, consultation and other modalities of employees involvement in the activity of the European company. The provisions to which the Law $\mathrm{nr} 31 / 1990$ refers are those applicable for the European companies registered in Romania.

According to the community regulations, the legal regime of participation in the company resulted from the cross-border merger is more flexible than the form of participation from an European company.

Concerning the European company resulted from the cross-border merger, paragraph 1 of Article 251 of the Law no 31/1990, it demands to fully apply the conditions of the Government Decision no 187/2007.

For those cases in which the company resulted from the cross-border merger is a Romanian legal person, paragraph 2 of art 251 of the law makes reference to Article 3 paragraph (1) and (2), Article 4-7, art 10 paragraph (1) and (2) letter a), g), and h), Article 1124, 27 and 28 of the Government Decision nr 187/2007, which contain the rules applicable to the special group of negotiation, to the agreement, to the duration of the negotation and to the standard rules.

The cited dispositions shall be supplemented with the ones from paragraph (3)-(6) of Law nr 31/1990 which, according to the dispositions of Article 16(2) and the following from the Directive 2005/56/CE, regulate special legal aspects for cases where the company 
resulting from the cross-border merger is a Romanian legal person, which derogates from the rules applicable European company..

Therefore, in accordance with the national legislation, the employee participation mechanisms regarding the company's activity can be determined through negotiation or by applying the standard reference provisions. The decision of applying the standard provisions may be made by each one of the parts, as follows :

a) the special negotiating body may decide not to start the negotiation or to stop them if they have been already initiated. If, after previous negotiations, the standard rules are applied, it is allowed to limitate the ratio of the employee representatives by the general meeting of the shareholders, with reducing the ratio of participation at minimum one third;

b) the management bodies of the participant companies may decide without a previous negotiation to apply the reference provisions or to respect them, from the date of registration in the trade register of the absorbing or newly created company modifier legislation.

An issue that may arise in this case is the fact that it has to be clarified why the Romanian legislator has chosen to distinguish between the hypothesis in which the manegement bodies obey the standard rules and that in which they understand to respect them from the time the cross-border merger enters into force.

Beyond the differences regarding the way of expressing the will to apply the standard rules, a possible reasoning of the legislator could be the that of covering the situations in which the applicability of the participation system could be invoked after cross-border registration.

Such a case could be the one of the" empty" companies, which at the time of the merger entry into force they do not have any employees. Regarding this hypothesis, the management bodies' possible decision to obey the reference provisions would be devoid of purpose in the absence of the employees and furthemore, in the absence of participation rights that should have been respected.

This is why we condition that the Romanian legislator has imagined the solution to an agreement of respecting the standard rules, on condition that the object of regulated protection exists, and that it may produce legal effects in the future, at the moment of the condition completion. Certainly, from this point on another set of questions arises.

For exemple, if we may consider the suspensive condition fulfilled in case in which the resulting company hires only Romanian citizens or it is necessary to also hire employees from other Member States, whose legislation governed the participant companies and provides participation mechanisms. Regardless of our opinion on these aspects, our questions emphasise the necessity of de lege ferenda legal rules on these aspects at European and national level.

The transposal of the provisions of Article 16 on cross-broder merger in the Romanian law is, in general terms, precise. However, in our law, the hypothesis in which at least one of the companies that participate to the merge has an average of over 500 employees for a period of six months before publishing the project of cross-border merger and is managed by an employee participation regime, is not regulated.

We may consider that the Romanian legislator regarded such a regulation as unnecessary, taking into consideration that the law of the legal seat cannot be applied on resulting companies establishing ther headquarters in Romania since this law does not provide participation formulas and the applicability of the "before-after" principle is guaranteed regardless if the number of employees who have previously benefited of participation rights is smaller or bigger than the average of 500 .

Still, from our point of view, the situation in which an European company with the headquarters in Romania participates to a cross-border merger, that, excepting the case in which it is registered as an empty entity, it applies a mechanism of participation and can enter in the area of applicability of the analysed community provision has been ignored . 


\section{Felicia Bejan}

For identity of reason, we believe that the Romanian legal person who applies a participation system and who later participates to a cross-border merger, and the resulted company establish the headquarters in Romania may also be circumscribed to the same area.

Thus, we underline the perfectibility of this legal framework of the Romanian law, proposing that de lege ferenda a judicial transposition of the analysed European provision should be done by national legislator

\section{CONCLUSIONS.}

The study of legal regime of employees' participation rights on the board of directors or supervisory board in companies resulting from a cross-border merger into various Member States revealed two important aspects of this legal issue.

On the one hand, as a rule, the participation rights is not highly implemented in the Member States. There is an exception, German law, which contains special legal rules in domanin, including even provisions having as purpose to protect against discrimination related to the exercise of participation right. In most Membres States, there are fewer rules or none. Consequently, the establishment of participation rights may be mandatory or noncompulsory, the forms of involvement vary from one Member State to another, the duration of negotiations is not harmonised with the necessity of merger efficiencies.

On the other hand, having as legal basis Article no. 16 of the Directive 2005/56/EC on cross-border mergers, completed with Regulation(EC) 2157/2001 in the Statute for a European company and with Directive 2001/86/EC supplementing the Statute for a European company with regard to the involvement of employee, legislative framework of Member States guarantees the application of „,before and after” principle. In essence, this principle ensured that the highest level of participation known before the cross-border merger in at least one of the participating companies is maintained in the company resulting from the reorganization.

In our opinion, de lege lata, taking into consideration these two aspects, in practice, participating companies have the possibility to choose as headquarter of resulting company from a cross-border merger those where the participating rights are more or less protected, depending on their own interests. De lege ferenda, for the purpose of raising the stability of employees participating level, we consider that the European legislator has to introduce more clear and comprehensive rules concerning employees' involvement and general function of the whole mechanism, by enacting a special Directive having as its object the employees' participation rights.

\section{REFERENCES}

1. I.T., Stefanescu, Theoretical and practical treaty, Bucharest: Universul Juridic Publishing House, 2012;

2. C. Lefter, Foundation of Institutional Community Law, Bucharest: Economic Publishing House, 2003;

3. F.Bejan, "European Union Rules on employee participation right within the framework of cross-border merger .", Advances in fiscal, political and law sciences, Proceedings of the 2nd International Conference on Economics, Political and Law Science (EPLS '13, 2013;

4. Lencou D. , Menjucq M., Les fusions transfrontalieres de sociétés de capitaux: enfin une réalité mais des difficultés persistantes!, Editura Dalloz , Paris, 2009;

5. Craig, P. and de Burca, G., Dreptul Uniunii Europene, Bucharest: Hamangiu, 2009;

6. Menjucq, M., Droit international et européen des sociétés, Domat droit privé, Montchrestien, 2008;

7. Council Regulation no. 2157/2001 on the Statute for a European Company published in the OJ 294/1 of November 10, 2001.; 
8. Directive 2001/86/EC supplementing the Statute for a European Company with regard to the involvement of employees published in the OJ L 294/22 of November 10, 2001;

9. Directive 2005/56/EC on cross-border mergers of limited liability companies published in the OJ L 310/1 of November 25, 2005;

10. Directive 78/855/EEC of 9 October 1978 concerning mergers of public limited liability companies published in the OJ L 295/36 of October 20, 1978. 